\title{
Potential Drug-drug Interactions Analysis in Children Out-patients with Bronchopneumonia Medication Prescriptions
}

Ilil Maidatuz Zulfa ${ }^{{ }^{*}(0)}$
Fitria Dewi Yunitasari ${ }^{1}$
Susanty Kartika Dewi ${ }^{2}$
1Department of Community Pharmacy,
Akademi Farmasi Surabaya, Surabaya,
East Java, Indonesia
2Pharmacy Diploma Program, Akademi
Farmasi Surabaya, Surabaya, East Java,
Indonesia
*email: ililmaidatuz@gmail.com
Keywords:
Drug Interactions
Bronchopneumonia
Children
Outpatients

\begin{abstract}
Drug-drug interactions (DDIs) is defined as the alteration of efficacy and toxicity of some drugs in the presence of other drugs. In the treatments of bronchopneumonia in outpatient settings, there is a lack of documentation of DDIs. This study was aimed to observe the potential DDIs on the prescriptions of children with bronchopneumonia. An observational and cross-sectional study was conducted on outpatient children with bronchopneumonia prescriptions during 2017. Potential for DDI was identified by online drug interaction checkers. The potential DDI then classified based on its severity (minor, moderate, and major) and mechanism (pharmacokinetic and pharmacodynamic). Among 86 prescriptions analyzed, potential DDIs observed at $48.84 \%$ of it. Of that, there were 67 potential DDIs where $72.34 \%$ of it were categorized as moderate. The majority of potential DDIs was pharmacodynamic interaction $(76.12 \%)$ with the most frequently involved drug pair was EphedrineSalbutamol (29.85\%). Children outpatients with bronchopneumonia are at risk of potential DDIs, especially to minor and moderate potential DDIs. Prescriptions screening for potential DDIs followed by monitoring of therapeutical effects and associated adverse drug events will optimize patient safety.
\end{abstract}

Received: March 20th 2020

Accepted: May 7th 2020

Published: May 21st 2020

(C) 2020 Ilil Maidatuz Zulfa, Fitria Dewi Yunitasari, Susanty Kartika Dewi. Published by Institute for Research and Community Services Universitas Muhammadiyah Palangkaraya. This is an Open Access article under the CC-BYSA License (http:/ / creativecommons.org/licenses/by-sa/4.0/). DOI: https://doi.org/10.33084/bjop.v3i2.1316

\section{INTRODUCTION}

Drug-drug interactions (DDIs) is defined as the change of efficacy and toxicity of some drugs in the presence of other drugs (Shetty et al., 2018). The alterations occure both in pharmacokinetics (absorbtion, distribution, metabolism, and excretion) and pharmacodynamics (sinergism, antagonism, and competition in receptors) phase (Kulkarni et al., 2013; Palleria et al., 2013). In the clinical settings, DDIs is the main source of adverse drug event (Somogyi-Vegh et al., 2019). A recent meta-analysis of several studies reports that DDIs has contributed to $1.1-5 \%$ of hospitalization and $0.25-25 \%$ of the adverse drug reaction related to hospitalization (Dechanont et al., 2014; Ismail et al., 2018). In outpatient settings, there is a lack documentation of DDIs and its prevalence is reported lower than in hospitalized patients because they are usually prescribed less drug combination (Vaidhun \& Sathish, 2011). However, if they are prescribed with polypharmacy the potential of DDIs occurence will also rise.

Bronchopneumonia is one of life-threatning pneumonia manifestation commonly occur in children under 5 y.o. As the treatment of pneumonia, causative management using antibiotics and symptomatic drugs like antitusive, expecorant, antihistamine, analgesic-antipyretic used in bronchopneumonia management (Harris et al., 2011; Chang et al., 2014). Hence, high combination drugs potentially prescribed to the children with 
bronchopnaumonia and its leading to the occurence of DDIs. The DDIs identification in bronchopneumonia prescriptions will optimize the outcome therapy and prevent the incidence of adverse drug reactions (Noor et al., 2019). This study was aimed to observe the potential DDIs on the prescriptions of children with bronchopneumonia.

\section{MATERIALS AND METHODS}

An observational and cross-sectional study was conducted on outpatient children with bronchopneumonia prescriptions during 2017 at a Hospital in Bangkalan, Madura Island, Indonesia. Study began after obtaining permition from the hospital. The Inclusion criteria were prescriptions of outpatient children age 0-14 y.o. diagnosed with bronchopneumonia without any infection comorbidities. Prescriptions contained one or two drugs with different route of administration were excluded. Potential for DDIs were identified by online drug interaction checkers from www.drugs.com. The drugs that not available in the database were than identified by www.drugbank.ca. The prescriptions contained drugs that not listed in that two online applications were also excluded. The potential DDIs then classified based on its severity (minor, moderate, and major) and mechanism (pharmacokinetic and pharmacodinamic). The management suggestion from the online applications also included.

\section{RESULTS AND DISCUSSION}

During the period of study, a total of 158 prescriptions met the inklusions criteria. Of that, 72 prescriptions were excluded due to varoous reasons; 9 prescriptions only contained of one drugs, 3 prescriptions contained of two drugs with different route; 10 prescriptions consisted of probiotics; and 50 remaining contained of herbal medicine like succus liquiritaeand echinaceae extract that not available in the the two online-application used. The remaining 86 prescriptions were analyzed for the potential DDIs. The prevalence of potential DDIs based on gender, age, and number of drug prescribed showed in patients characteistics as presented in Table I.

Table I. Patients characteristics

\begin{tabular}{|c|c|c|c|}
\hline \multirow[b]{2}{*}{ Characteristics } & \multicolumn{2}{|c|}{$\mathbf{N}(\%)$} & \multirow[b]{2}{*}{ Total (\%) } \\
\hline & $\begin{array}{c}\text { Potential } \\
\text { DDIs }\end{array}$ & $\begin{array}{c}\text { No Potential } \\
\text { DDIS }\end{array}$ & \\
\hline \multicolumn{4}{|l|}{ Gender } \\
\hline Female & $19(22.09)$ & $24(27.91)$ & $43(50.00)$ \\
\hline Male & $23(26.74)$ & $20(23.26)$ & $43(50.00)$ \\
\hline Total & $42(48.84)$ & 44 (51.16) & $\begin{array}{c}86 \\
(100.00)\end{array}$ \\
\hline \multicolumn{4}{|l|}{ Age (years) } \\
\hline$<1$ & 13 (15.12) & $2(2.33)$ & $15(17.44)$ \\
\hline $1-5$ & $21(24.42)$ & $35(40.70)$ & $56(65.12)$ \\
\hline $6-10$ & $5(5.81)$ & $7(8.14)$ & 12 (13.95) \\
\hline $11-14$ & $3(3.49)$ & $0(0.00)$ & $3(3.49)$ \\
\hline Total & $42(48.84)$ & $44(51.16)$ & $\begin{array}{c}86 \\
(100.00) \\
\end{array}$ \\
\hline \multicolumn{4}{|l|}{$\begin{array}{l}\text { Number of drug } \\
\text { prescribed }\end{array}$} \\
\hline$<5$ & $30(34.88)$ & 10 (11.63) & $40(46.51)$ \\
\hline $5-10$ & $7(8.14)$ & $21(24.42)$ & $28(32.56)$ \\
\hline$>10$ & $5(5.81)$ & 13 (15.12) & $18(20.93)$ \\
\hline Total & $42(48.84)$ & 44 (51.16) & $\begin{array}{c}86 \\
(100.00) \\
\end{array}$ \\
\hline
\end{tabular}

Generally, the prevalence of potential DDIs is linear to the number of drug prescribed as Loya et al. (2009) reported that $46.2 \%$ dan $72.3 \%$ of polypharmacy had at least one potential DDIs. However, in this study the majority potential DDIs observed in the prescriptions contained less than five drugs. This discrepancy might be due to the prescribing culture and formulary used in the hospital. Out of the 42 potential DDIs found, most of them had moderate $(80.95 \%)$ and minor $(73.80 \%)$ severity that is sufficiently to warn us to have a monitoring for the potential dangerous, as shown in Figure 1.

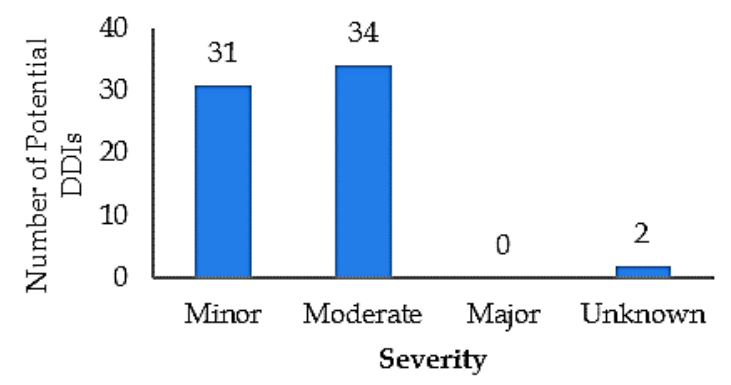

Figure 1. Severity of Potential DDIs 
The prevalence of potential DDIs, its manifestations, and suggested management predominantly occur in the pharmacodynamic phase, as presented in Table II. The higher number of pharmacodynamics DDIs are probably due to the drug combinations prescribed is purposed to enhance the efficacy (Patel et al, 2014). The pair of ephedrine+salbutamol was counted $29.85 \%$ of pharmacodynamics DDIs and potentially harm to patients as it has moderate severity. The manifestation is similar to pseudoephedrine+salbutamol which was observed $4.48 \%$ of pharmacodynamics DDIs in this study. The administration of beta- 2 agonists together with other adrenergic agents may result in the increase of cardiovascular side effects including escalation of pulse rate and systolic or diastolic blood pressure as well as ECG changes such as flattening of the $\mathrm{T}$ wave, prolongation of the QTc interval, and ST segment depression. These effects may be more common when the drugs are administered systemically or when recommended dosages are exceeded (Khalilian et al., 2016). A meta-analysis by Salpeter et al. (2004) reported that beta-2 agonist use in patients with obstructive airway disease increases the risk for cardiovascular adverse events from three days to one year. The manifestation occure were an increase in heart rate and potassium concentrations depletion. Therefore, the oral concomitant use of ephedrine+salbutamol in children with bronchopneumonia must be counted for its benefit and risk. Use salbutamol in local route like inhaler will minimize the risk of cardiovascular event.

Another pharmacodynamic DDIs that need to be considered was from the pair of dexamethasone+teophyline. The co-administration of theophylline and corticosteroids theoretically may potentiate the risk of hypokalemia due to additive potassium-lowering effects. Theophylline inhibits adenosine receptors and blocks phosphodiesterase causing rised cyclic adenosine monophosphate resulting in increased levels of adrenergic activation and catecholamine release at larger dose (Barnes, 2010). Elevated catecholamine concentrations will lead to adverse effects such as metabolic acidosis, hyperglycemia, cardiac arrhythmias, and hypokalemia (Kardalas et al., 2018). Additionally, corticosteroids conduce sodium retention through the increase of sodium tubular absorption and potassium excretion. Sodium retention and potassium loss may result in hypokalemic alkalosis in patients receiving glucocorticoids (Nasralla et al., 2010). Consequently, if the benefits outweight the drawbacks, the use of dexamethasone and theophylline in children with bronchopneumonia should be followed by monitoring in potassium levels and the cardiovascular events (Zec et al., 2016).

In the pharmacokinetics phase, the most common DDIs observed was ephedrine+vitamin C. Acidic urine increases the urinal elimination of ephedrine. However, the severity is minor and the clinical significance is unknown.

Table II. Prevalence of potential DDIs

\begin{tabular}{|c|c|c|c|}
\hline Drug pairs & $\begin{array}{l}\mathbf{N}(\%) / \\
\text { severity }\end{array}$ & $\begin{array}{c}\text { Potential } \\
\text { Manifestasion }\end{array}$ & Management \\
\hline \multicolumn{4}{|c|}{ Pharmacokinetics DDIs } \\
\hline Ephedrine-Vitamin & $9(13.43)$ & The effect of & Considering \\
\hline $\mathrm{C}$ & / Minor & $\begin{array}{c}\text { ephedrine may be } \\
\text { decreased }\end{array}$ & $\begin{array}{l}\text { for drug } \\
\text { subtitution }\end{array}$ \\
\hline Phenytoin- & $2(2.99) /$ & The effect of & Considering \\
\hline Dexamethasone & Moderate & $\begin{array}{l}\text { dexamethasone } \\
\text { may be decreased }\end{array}$ & $\begin{array}{l}\text { for drug } \\
\text { subtitution }\end{array}$ \\
\hline Phenytoin- & $2(2.99) /$ & The potential & Monitoring on \\
\hline Paracetamol & Moderate & $\begin{array}{l}\text { hepatotoxicity of } \\
\text { paracetamol may be } \\
\text { increased and its } \\
\text { pharmacological } \\
\text { effects may be } \\
\text { decreased }\end{array}$ & liver function \\
\hline Total & & $13(19.40)$ & \\
\hline \multicolumn{4}{|c|}{ Pharmacodynamics DDIs } \\
\hline $\begin{array}{l}\text { Chlorphenyramine } \\
\text { - Domperidone }\end{array}$ & $\begin{array}{l}1(1.49) / \\
\text { Unknown }\end{array}$ & $\begin{array}{c}\text { The effect on } \\
\text { cardiovascular } \\
\text { may be increased }\end{array}$ & $\begin{array}{l}\text { Monitoring of } \\
\text { the presence of } \\
\text { arrhythmia }\end{array}$ \\
\hline Chlorphenyramine & $1(1.49) /$ & The effect on CNS & Monitoring on \\
\hline - Codein & Moderate & may be increased & $\begin{array}{l}\text { respiration } \\
\text { function }\end{array}$ \\
\hline $\begin{array}{l}\text { Dexamethasone } \\
\text { + Salbutamol }\end{array}$ & $\begin{array}{l}9(13.43) \\
/ \text { Minor }\end{array}$ & $\begin{array}{l}\text { The effect on } \\
\text { cardiovascular } \\
\text { may be increased }\end{array}$ & $\begin{array}{l}\text { Monitoring of } \\
\text { the presence of } \\
\text { arrhythmia }\end{array}$ \\
\hline
\end{tabular}




\begin{tabular}{|c|c|c|c|}
\hline $\begin{array}{l}\text { Dexamethasone } \\
+ \text { Teophyline }\end{array}$ & $\begin{array}{l}4(5.97) / \\
\text { Moderate }\end{array}$ & $\begin{array}{l}\text { The effect on } \\
\text { cardiovascular } \\
\text { may be increased }\end{array}$ & $\begin{array}{l}\text { Monitoring } \\
\text { for altered } \\
\text { efficacy and } \\
\text { safety of } \\
\text { theophylline } \\
\text { and altered } \\
\text { serum } \\
\text { potassium }\end{array}$ \\
\hline $\begin{array}{l}\text { Ephedrine + } \\
\text { Salbutamol }\end{array}$ & $\begin{array}{c}20(29.85) / \\
\text { Moderate }\end{array}$ & $\begin{array}{l}\text { The effect on } \\
\text { cardiovascular } \\
\text { may be increased }\end{array}$ & $\begin{array}{l}\text { Monitoring for } \\
\text { blood pressure } \\
\text { and heart rate }\end{array}$ \\
\hline $\begin{array}{l}\text { Ephedrine - } \\
\text { Teophylin }\end{array}$ & $\begin{array}{l}1(1.49) / \\
\text { Minor }\end{array}$ & $\begin{array}{l}\text { The potential side } \\
\text { effects like nausea, } \\
\text { vommiting, } \\
\text { tachycardia and } \\
\text { insomnia may be } \\
\text { increased }\end{array}$ & $\begin{array}{l}\text { Monitoring of } \\
\text { the presence of } \\
\text { side effects }\end{array}$ \\
\hline $\begin{array}{l}\text { Methylprednisolon } \\
+ \text { Salbutamol }\end{array}$ & $\begin{array}{l}9(13.43) \\
\text { / Minor }\end{array}$ & $\begin{array}{l}\text { The hypokalemia } \\
\text { risk and the effect } \\
\text { on cardiovascular } \\
\text { may be increased }\end{array}$ & $\begin{array}{l}\text { Monitoring for } \\
\text { serum } \\
\text { potassium } \\
\text { level and the } \\
\text { presence of } \\
\text { arrhythmia }\end{array}$ \\
\hline $\begin{array}{l}\text { Prednison- } \\
\text { Salbutamol }\end{array}$ & $\begin{array}{l}1(1.49) / \\
\text { Minor }\end{array}$ & $\begin{array}{l}\text { The hypokalemia } \\
\text { risk and the effect } \\
\text { on cardiovascular } \\
\text { may be increased }\end{array}$ & $\begin{array}{l}\text { Monitoring for } \\
\text { serum } \\
\text { potassium } \\
\text { level and the } \\
\text { presence of } \\
\text { arrhythmia }\end{array}$ \\
\hline $\begin{array}{l}\text { Pseudoephedrine- } \\
\text { Salbutamol }\end{array}$ & $\begin{array}{l}3(4.48) / \\
\text { Moderate }\end{array}$ & $\begin{array}{l}\text { The effect on } \\
\text { cardiovascular } \\
\text { may be increased }\end{array}$ & $\begin{array}{l}\text { Monitoring for } \\
\text { blood pressure } \\
\text { and heart rate }\end{array}$ \\
\hline $\begin{array}{l}\text { Salbutamol- } \\
\text { Teophyline }\end{array}$ & $\begin{array}{l}1(1.49) / \\
\text { Moderate }\end{array}$ & $\begin{array}{l}\text { The hypokalemia } \\
\text { risk and the effect } \\
\text { on cardiovascular } \\
\text { may be increased }\end{array}$ & $\begin{array}{l}\text { Monitoring for } \\
\text { serum } \\
\text { potassium } \\
\text { level and the } \\
\text { presence of } \\
\text { arrhythmia }\end{array}$ \\
\hline $\begin{array}{l}\text { Cetirizin- } \\
\text { Sodium } \\
\text { Valproate }\end{array}$ & $\begin{array}{l}1(1.49) / \\
\text { Moderate }\end{array}$ & $\begin{array}{l}\text { The effect on CNS } \\
\text { may be increased }\end{array}$ & $\begin{array}{l}\text { Monitoring for } \\
\text { cognitif } \\
\text { function }\end{array}$ \\
\hline Total & & $53(76.12)$ & \\
\hline \multicolumn{4}{|c|}{ Unknown mechanism DDIs } \\
\hline $\begin{array}{l}\text { Dexamethasone } \\
\text { - Ephedrine }\end{array}$ & $\begin{array}{c}2(2,99) / \\
\text { Minor }\end{array}$ & $\begin{array}{c}\text { The effect of } \\
\text { dexamethasone } \\
\text { may be decreased }\end{array}$ & $\begin{array}{l}\text { Considering } \\
\text { for drug } \\
\text { subtitution }\end{array}$ \\
\hline $\begin{array}{c}\text { Domperidone- } \\
\text { Paracetamol }\end{array}$ & $\begin{array}{l}1(1,49) / \\
\text { Unknown }\end{array}$ & $\begin{array}{c}\text { The serum level of } \\
\text { domperidone may } \\
\text { be increased }\end{array}$ & $\begin{array}{l}\text { Considering } \\
\text { for drug } \\
\text { subtitution }\end{array}$ \\
\hline Total & & $3(4.48)$ & \\
\hline Total & & $67(100.00)$ & \\
\hline
\end{tabular}

Apart from the result above, this study has several limitations. As this study showed the potential for DDIs in the prescriptions, the actual occurr of DDIs in the patients could not be determined because the study was a single point cross-sectional and out-patient based. Moreover, herbal medicine and probiotics-contained prescriptions could not be determined for the DDIs. Therefore, future studies on potential and actual occurrence DDIs in outpatient children with bronchopneumonia in future still need to be conducted.

\section{CONCLUSION}

A considerable prevalence of potential DDIs has been observed in children outpatients with bronchopneumonia (48.84\%) where moderate potential DDIs were the most common. Moreover, the use of probiotics and herbal medicine in bronchopneumonia treatments still need to be considered related unknown potential DDIs. Prescriptions screening for potential DDIs followed by monitoring of therapeutical effects and associated adverse drug events will optimize patient safety.

\section{ACKNOWLEDGMENT}

We would like to express our deep sense of gratitude to the Hospital for their permition and support during data collection. We would also thank to Akademi Farmasi Surabaya for the financial support during this study.

\section{REFERENCES}

Barnes, P.J. (2010). Theophylline. Pharmaceuticals, 3(3), 725-747. doi:10.3390/ph3030725

Chang C.C., Cheng A.C., \& Chang A.B. (2014). Over-thecounter medications to help reduce cough for children and adults on antibiotics for acute pneumonia. Cochrane Database of Systematic Reviews, 3, CD006088. doi:10.1002/14651858.CD006088.pub4

Dechanont, S., Maphanta, S., Butthum, B., \& Kongkaew, C. (2014). Hospital admissions/visits associated with drug-drug interactions: a systematic review and meta-analysis. Pharmacoepidemiology and Drug Safety, 23(5), 489-497. doi:10.1002/pds.3592

Harris, M., Clark, J., Coote, N., Fletche, P., Harnden, A., McKean, M., \& Thomson, A. (2011). British Thoracic Society guidelines for the management of community acquired pneumonia in children: update 2011. Thorax, 66(Suppl 2), 1-23. doi:10.1136/thoraxjnl-2011200598 
Ismail, M., Noor S., Harram U., Haq I., Haider I., Khadim F., Khan Q., Ali Z., Muhammad T., \& Asif M. (2018). Potential drug-drug interactions in outpatient department of a tertiary care hospital in Pakistan: a cross-sectional study. BMC Health Services Research, 18(1), 762. doi:10.1186/s12913-018-3579-7

Kardalas, E., Paschou, S.A., Anagnostis, P., Muscogiuri, G., Siasos, G., \& Vryonidou, A. (2018). Hypokalemia: a clinical update. Endocrine Connections, 7(4), 135-146. doi:10.1530/EC-180109

Khalilian, M.R., Fayezi, A., Alisamir, M., \& Khorasani, N.M. (2016). Effect of Ventolin on QTc in children with respiratory distress. Journal of Cardiovascular and Thoracic Research, 8(2), 83-85. doi:10.15171/jcvtr.2016.16

Kulkarni, V., Bora, S.S., Sirisha S., Saji, M., \& Sundaran, S. (2013). A study on drug-drug interactions through prescription analysis in a South Indian teaching hospital. Therapeutic Advances in Drug Safety, 4(4), 141-146. doi:10.1177/2042098613490009

Loya, A.M., Gonz'alez-Stuart, A., \& Rivera, J.O. (2009). Prevalence of polypharmacy, polyherbacy, nutritional supplement use and potential product interactions among older adults living on the United States-Mexico border: a descriptive, questionnaire-based study. Drugs and Aging, 26(5), 423-436. doi:10.2165/00002512-200926050-00006

Nasralla, H.A.A., Al-Hilaly, K.A., \& Alghabban, S.I. (2010). Drug induced Hypokalemia: A Retrospective Study. New Iraqi Journal of Medicine, 6(1), 22-26.

Noor, S., Ismail, M., \& Ali, Z. (2019). Potential drug-drug interactions among pneumonia patients: do these matter in clinical perspectives? $B M C$ Pharmacology and Toxicology, 20, 45. doi:10.1186/s40360-019-0325-7

Palleria, C., Di Paolo, A., Giofre, C., Caglioti, C., Leuzzi, G., Siniscalchi, A., De Sarro, G., \& Gallelli, L. (2013). Pharmacokinetic drug-drug interaction and their implication in clinical management. Journal of Research in Medical Sciences, 18(7), 601610.

Patel, P.S., Rana, D.A., Suthar, J.V., Malhotra. S.D., \& Patel, V.J. (2014). A study of potential adverse drug-drug interactions among prescribed drugs in medicine outpatient department of a tertiary care teaching hospital. Journal of Basic and Clinical Pharmacy, 5(2), 44-48. doi:10.4103/0976-0105.134983

Salpeter, S.R, Ormiston, T.M., \& Salpeter, E.E. (2004). Cardiovascular effects of beta-agonists in patients with asthma and COPD: a metaanalysis. Chest, 125(6), 2309-2321. doi:10.1378/chest.125.6.2309

Shetty, V., Chowta, M.N., Chowta, K.N., Shenoy, A., Kamath, A., \& Kamath, P. (2018). Evaluation of Potential Drug-Drug Interactions with Medications Prescribed to Geriatric Patients in a Tertiary Care Hospital. Journal of Aging Research, 2018, 5728957. doi:10.1155/2018/5728957

Somogyi-Végh, A., Ludányi, Z., Erdős, Á., \& Botz, L. (2019). Countrywide prevalence of critical drug interactions in Hungarian outpatients: a retrospective analysis of pharmacy dispensing data. BMC Pharmacology and Toxicology, 20(1), 36. doi:10.1186/s40360-019-0311-0

Vaidhun, B.H. \& Sathish, A. (2011). Out-patients Prescriptions are Safe from Drug Interactions or Not: A Pilot Study Report. Indian Journal of Pharmaceutical Sciences, 73(5), 590-592. doi:10.4103/0250-474X.99024

Zec, S.L., Selmanovic, K., Andrijic, N.L., Kadic, A., Zecevic, L., \& Zunic, L. (2016). Evaluation of Drug Treatment of Bronchopneumonia at the Pediatric Clinic in Sarajevo. Medical Archives, 70(3), 177-181. doi:10.5455/medarh.2016.70.177-181 